\title{
Pembangunan Game Memory Training terhadap Peningkatan Short Term Memory (STM) pada Anak SMP Menggunakan Speech Recognition (Studi Kasus: SMP Dharma Loka Pekanbaru)
}

\author{
Raymond $^{a}$, Rahmat Suhatman ${ }^{b}$ dan Meilany Dewi \\ a,b,c Politeknik Caltex Riau,Jl.Umban Sari No. 1, Pekanbaru, Indonesia
}

\section{INFORMASI ARTIKEL}

Sejarah Artikel:

Diterima Redaksi: 23 Februari 2018

Revisi Akhir: 06 Juni 2018

Diterbitkan Online: 31 Agustus 2018

\begin{tabular}{l} 
KATA KUNCI \\
\hline Game Memory Training, \\
Short Term Memory, \\
Speech Recognition \\
KORESPONDENSI \\
\hline
\end{tabular}

Telepon: +6281367501010

E-mail: raymond14ti@mahasiswa.pcr.ac.id

\section{A B S $\mathbf{S}$ T $\mathbf{R}$ A $\mathbf{C}$ T}

The early teen phase is a phase where humans have reached the age from 12 to 15 years old and have been in Junior High School. When people has entered this phase, there will be emotional instability which accompanied by physical growth, desire to explore something, and uncontrolled feeling to be governed by others. If this can not be solved well, it can decrease the system or work in human brain, it can be marked by the decrease in Short Term Memory (STM) associated with the sensory nerves work system, making the students more difficult to remember the lessons that delivered by the teachers at school and contents of the conversation that has just been discussed. If this is continuously, the risk of students exposed to dementia problems will be greater and the impact will be felt on the old days of students slowly, because the brain is not given training for memory updates. Game Memory Training development is using speech recognition that has been tested on the students of Dharma Loka Junior High School Pekanbaru. Game Memory Training is built to improve students' Short Term Memory about $93.9 \%$ for Memory Test which refers to the IST form and $69.7 \%$ for Concentration Test which refers to the Wechsler form.

\section{PENDAHULUAN}

Fase remaja awal merupakan salah satu fase perkembangan siklus hidup pada manusia. Menurut Rumini \& Sundari (2004), seseorang dikatakan remaja awal jika telah menginjak usia 12 sampai dengan 15 tahun. Pada tahap usia remaja awal inilah banyak siswa telah duduk dibangku Sekolah Menengah Pertama (Kartono, 1990). Saat seseorang telah memasuki fase remaja, maka akan terjadi ketidakstabilan emosi yang diiringi dengan pertumbuhan fisik, keinginan untuk bereksplorasi, dan timbul perasaan tidak ingin diatur oleh orang lain. Jika hal tersebut tidak dapat diatasi dengan baik, maka dapat menimbulkan penurunan sistem atau fungsi kerja pada otak manusia yang ditandai dengan penurunan daya rangsangan dan respon dari saraf sensorik dan motorik, salah satunya, berkurangnya kemampuan Short Term Memory (Hurlock, 1991).

Dari hasil wawancara langsung dengan Bapak Johan Wyanaputra, S.Ag., M.Pd. selaku kepala sekolah SMP Dharma Loka Pekanbaru, beliau sering mendengar keluhan dari para guru, bahwa kemampuan mengingat sebagian siswa yang masih rendah, seperti tidak dapat mengulang materi yang baru saja diterangkan oleh bapak/ibu guru dipapan tulis dan mengalami kesulitan untuk mengingat materi yang telah diajarkan, terutama pada pelajaran yang membutuhkan hafalan yang kuat, jika tidak diatasi maka dapat mempengaruhi nilai akademik dan akreditasi

https://doi.org/10.25077/ TEKNOSI.v4i2.2018.061-072 sekolah. Di SMP Dharma Loka Pekanbaru sendiri, terdapat kegiatan senam INLA, siraman rohani, dan meditasi pada hari tertentu yang menurut Bapak Johan Wyanaputra, S.Ag., M.Pd. dapat membantu meningkatkan daya ingat para siswa, namun belum cukup signifikan dalam membantu proses belajar mengajar.

Menurut Ibu Dra. Erni Yulial, S.Psi. selaku psikolog klinis,penurunan daya ingat pada Short Term Memory (STM) terjadi secara perlahan-lahan yang dapat membuat manusia lebih sukar untuk mengingat sebuah peristiwa yang baru saja terjadi, tempat peletakan barang yang dibawa, mengulang informasi atau materi yang baru saja disampaikan oleh bapak/ibu guru di sekolah, dan isi percakapan yang belum lama dibicarakan bersama orang lain. Jika hal ini dibiarkan terus menerus, maka resiko para siswa SMP terkena masalah kepikunan semakin besar yang dampaknya baru dapat dirasakan dihari tua siswa tersebut. Salah satu media untuk melatih Short Term Memory (STM) adalah dengan melakukan pembangunan game untuk meningkatkan kemampuan Short Term Memory (STM) pada siswa SMP yang dapat mengacu pada form Wechsler-bellevue Intelligence pada bagian Digit Span dan Intelligenz Structure Test (IST) pada bagian Merk Aufgaben (ME). Menurut Bapak Johan Wyanaputra, S.Ag., M.Pd. dan Ibu Dra. Erni Yulial, S.Psi., banyak siswa atau anak remaja sekarang gemar bermain game. Bermain game dapat menimbulkan keinginan belajar atau latihan yang lebih interaktif, karena disajikan dengan audio bertempo 
lambat yang dapat memberikan ketenangan, membuat otak berkonsentrasi untuk menerima informasi dan mengingat kembali informasi yang telah disimpan (Jones, 2010; Pope, 2017), dan disajikan dengan tampilan yang menarik, sehingga menimbulkan keinginan yang lebih besar untuk melakukan latihan. Terakhir, wawancara dilakukan dengan Velika Wijaya melalui via telepon, yang sekarang ini telah duduk dibangku semester 7 Fakultas Psikologi Universitas Indonesia. Menurut beliau, dalam pengembangan game ini sebaiknya menerapkan teori dari Miller (1956), yaitu "The Magical Number Seven, Plus or Minus Two" mengenai jumlah items yang dapat disimpan didalam Short Term Memory (STM) manusia yang memiliki range 5-9 atau $7 \pm 2$ items dan teori ini telah diimplementasikan pada test Wechsler pada bagian Digit Span.

Berdasarkan kebutuhan diatas, maka dibangun Game Memory Training untuk membantu meningkatkan kemampuan Short Term Memory (STM) siswa SMP Dharma Loka Pekanbaru, pembangunan game ini berbasis Android, karena untuk melakukan latihan dapat dilakukan kapan dan dimana saja (fleksibel) dan berdasarkan hasil survey yang telah dilakukan, perangkat Android merupakan perangkat yang paling banyak digunakan oleh peserta didik SMP Dharma Loka Pekanbaru yang terkait dengan pengujian. Pembangunan Game Memory Training ini menggunakan tools Unity dan modeling objek menggunakan tools Blender dan Photoshop, objek yang dibuat berbentuk objek $2 \mathrm{D}$, karena hanya terdiri dari objek angka dan kata-kata yang mengacu pada form Wechsler-bellevue Intelligence dan Intelligenz Structure Test (IST). Adapun penggunaan speech recognition sebagai fitur masukkan jawaban pada game untuk melafalkan kembali susunan pengacakan angka secara forward dan backward pada Concentration Test yang mengacu pada form Wechsler, begitu juga untuk Memory Test dalam mengulang kembali kategori dan kata-kata yang disajikan pada game, yang mengacu pada form IST. Pada Game Memory Training ini, masukkan jawaban (suara) menggunakan Bahasa Inggris karena menurut Bapak Johan Wyanaputra, S.Ag., M.Pd., Bahasa Inggris merupakan bahasa internasional dan menjadi bahasa yang telah lazim digunakan untuk perancangan game saat ini. Game Memory Training ini dibangun untuk dapat membantu meningkatkan kemampuan Short Term Memory (STM), memvisualisasikan nilai yang didapatkan melalui permainan, dan melihat perkembangan memori jangka pendek siswa SMP Dharma Loka Pekanbaru.

\section{TINJAUAN PUSTAKA}

\subsection{Game}

Menurut Trisnadoli (2015) dalam jurnal "Analisis Kebutuhan Kualitas Perangkat Lunak pada Software Game Berbasis Mobile”, game adalah sebuah sistem yang memiliki kumpulan aturan-aturan buatan yang melibatkan pemain dengan tujuan untuk menghibur. Game berisikan skenario yang tersusun dari kumpulan audio dan visual yang menarik, sehingga membuat pemain dapat menikmati jalannya permainan yang disajikan pada game tersebut.

\subsection{Form Wechsler Bellevue Intelligence}

Form Wechsler Bellevue Intelligence merupakan salah satu alat test psikologi inteligensi dan kecerdasan yang ditemukan oleh David Wechsler dan diperkenalkan pada tahun 1939. Dimana pada form ini skalanya disebut dengan WAIS-R yang terdiri dari dua bentuk penyampaian test, yaitu skala verbal dan skala performance. Salah satu contoh dari skala verbal, yaitu test Digit Span. Test Digit Span ini bertujuan untuk melatih daya ingat, yang dimana terdapat dua bagian dari subtest rentang angka, yaitu forward (pengulangan bilangan dari deret awal-akhir) dan juga backward (pengulangan bilangan dari deret akhir-awal).
Adapun rumus perhitungan score pada Form Wechsler Bellevue dibagian Digit Span, yaitu jumlah butir soal yang benar setelah tester yang dimaksud benar dalam pelafalannya, kemudian dimasukan kedalam butir soal yang benar dijawab (row score), setelah itu dimasukkan ke scala score berdasarkan range usianya.

\subsection{Form Intelligenz Structure Test (IST)}

Dikembangkan oleh Rudolf Amthauer di Frankurt, Jerman pada tahun 1953. Tujuan adanya test ini yaitu untuk menggambarkan pola kerja tertentu, sehingga cocok untuk menggambarkan profesi atau pekerjaan yang sesuai dengan individu tersebut, karier, pendidikan, dan pengambilan keputusan. Form ISTini terdiri dari 9 subtest, salah satunya ME (Merk Aufgaben). Subtest ME (Merk Aufgaben) digunakan untuk mengukur daya ingat jangka pendek seseorang dan kemampuan konsentrasi dengan menyediakan kata-kata yang tersusun dalam lima kategori, dimana masing-masing kategori tersebut terdiri dari lima kata yang harus diingat.

Adapun rumus perhitungan score pada form Intelligenz Structure Test (IST) dibagian ME (Merk Aufgaben), yaitu jumlah butir soal yang benar (row score) yang berhasil dijawab, kemudian dimasukan kedalam skala berdasarkan standard pendidikan yang disebut dengan weighted score.

\subsection{Jenis Memory pada Manusia}

Menurut Atkinson dan Shiffrin (dalam Matlin, 1998), ingatan disimpan dalam tiga sistem penyimpanan informasi, yaitu memori sensori (sensory memory), memori jangka pendek (short term memory), dan memori jangka panjang (long term memory).

\section{Memori Sensori(Sensory Memory)}

Memori sensori adalah ingatan yang berkaitan dengan penyimpanan informasi sementara yang dibawa oleh pancaindra. Ketika mendengar, melihat, dan meraba sesuatu. Informasiinformasi dari panca indra diubah kedalam bentuk impuls-impuls neural (berbentuk neuron) dan dikirim ke otak. Proses tersebut berlangsung dalam hitungan detik.

\section{Ingatan Jangka Pendek(Short Term Memory)}

Merupakan proses penyimpanan memori sementara. Ingatan jangka pendek adalah tempat penyimpanan ingatan yang baru saja dipikirkan. Ingatan yang masuk dalam memori sensori diteruskan pada ingatan jangka pendek. Jika berhenti memberikan perhatian pada objek yang ingin kita ingat, maka akan terhapus dalam waktu 10-20 detik. Jumlah informasi yang bisa disimpan sangatlah terbatas, hanya lima sampai dengan sembilan informasi saja yang dapat berada dalam memori jangka pendek.

\section{Ingatan Jangka Panjang(Long Term Memory)} Proses memori atau ingatan yang bersifat permanen, informasi yang disimpan dapat bertahan dalam waktu yang sangat panjang. Kapasitas yang dimiliki oleh ingatan jangka panjang tidak terbatas.

\subsection{Speech Recognition}

Speech recognition atau teknologi pengenalan suara adalah teknologi yang menggunakan peralatan dengan sumber masukannya adalah suara, seperti microphone untuk menginterpretasikan suara manusia sebagai metode alternatif berinteraksi dengan computer untuk memasukkan tindakan atau perlakuan yang ingin dijalankan. Teknologi pengenalan suara tidak sama dengan teknologi voice recognition yang hanya mengenali suara sebagai identifikasi keamanan. Sistem komersial untuk pengenalan suara telah ada sejak 1990. Dengan 
menggunakan teknologi pengenalan suara memungkinkan pengguna untuk berbicara secara langsung, cepat, dan efisien (Permadi, 2008).

\section{PERANCANGAN}

\subsection{Arsitektur Game}

Arsitektur perancangan Game Memory Training pada proyek akhir ini dapat dilihat pada Gambar 1.

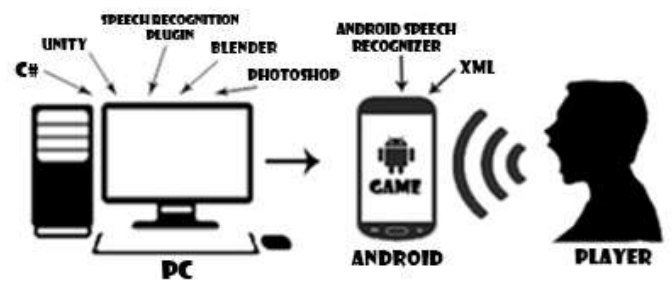

Gambar 1. Arsitektur Game Memory Training

Pada Gambar 1, awalnya game dibangun pada perangkat komputer menggunakan game engineUnity dengan bahasa pemrograman C\#, modeling objek menggunakan Blender dan Photoshop hingga menjadi sebuah game yang dapat dimainkan pada perangkat Android, dimana disini player memasukkan jawaban berupa suara menggunakan Android Speech Recognition pada library yang sudah disediakan sebelumnya pada asset di Unity, penyimpanan data yang didapatkan oleh player (siswa SMP) pada game menggunakan $X M L$ yang nantinya dimasukkan ke dalam folder Unity setelah build game selesai pada Android.

\subsection{Perancangan Usecase Diagram}

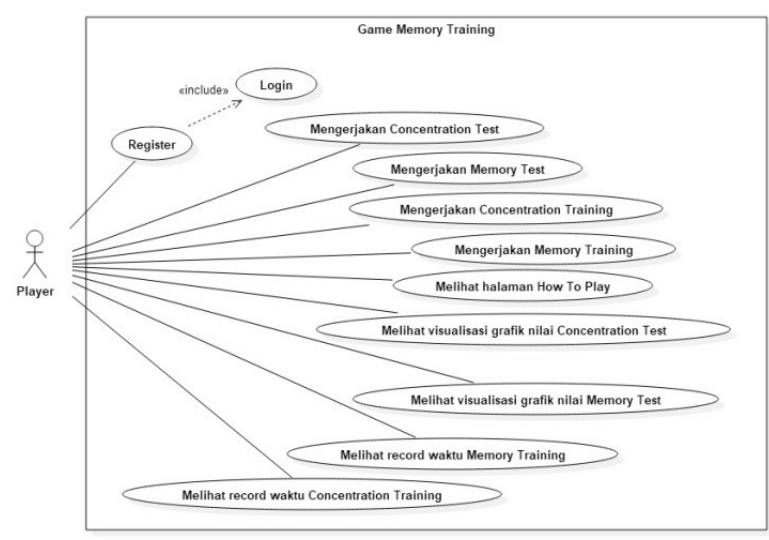

Gambar 2. Usecase Diagram Game Memory Training

\subsection{Diagram Blok Game Memory Training}

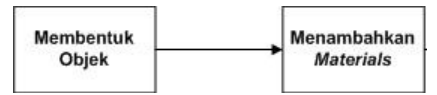

Gambar 3. Diagram Blok Pembuatan Objek 2D Game Memory Training

Pada Gambar 3 terdapat diagram blok yang menjelaskan cara pembangunan objek 2D yang digunakan pada pembangunan Game Memory Training menggunakan tools Blender dan Photoshop. Pada Blender, dilakukan pembentukan objek yang nantinya diberikan materials. Materials ini berisi gambar berupa angka dan palang yang telah didesain sebelumnya pada tools Adobe Photoshop CC 2015.

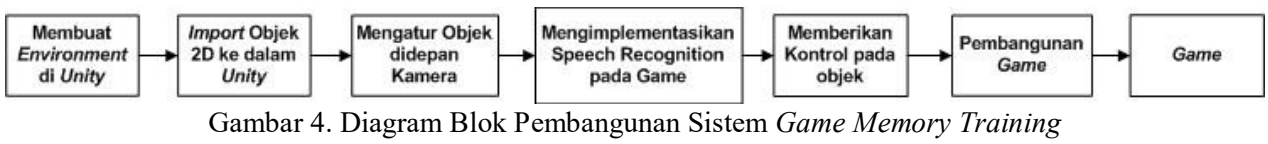

Pada Gambar 4, dilakukan pembuatan environment atau wilayah pada game yang dibuat. Setelah itu, import objek 2Dke dalam Unity. Kemudian, melakukan pengaturan pada objek yang berada didepan kamera, melakukan implementasi speech recognition pada game, dan berikan kontrol pada objek 2D yang telah kita import pada Unity. Setelah itu, lakukan proses pembangunan game hingga akhirnya menjadi sebuah game yang dapat dimainkan pada perangkat Android.

\subsection{Story Telling}

Game Memory Training yang dibangun memiliki karakteristik Game as media, dimana game ini dapat digolongkan ke dalam edugame, karena didalam game tersebut pengguna (siswa SMP) menggunakan media berupa game yang dibangun untuk melakukan latihan dan test untuk meningkatkan kemampuan memori jangka pendek pengguna (siswa SMP). Pada saat Game Memory Training ini dijalankan, pemain (siswa SMP) diarahkan ke tampilan awal, disini pemain harus menekan button Start untuk dapat meneruskan ke tampilan selanjutnya, dimana pada tampilan selanjutnya, pemain (siswa SMP) diminta untuk melakukan input NISN. Bagi pemain yang belum pernah masuk ke dalam game harus melakukan registrasi terlebih dahulu agar dapat memainkan game ini. Jika pemain (siswa SMP) yang sudah pernah masuk atau memainkan game ini, maka dapat langsung melakukan proses login. Setelah berhasil memasukkan NISN pada game, maka selanjutnya ditampilkan tampilan Home, dimana terdiri dari 3 button yaitu How To Play, Play, dan juga Result.

Pemain memilih button How To Play, maka menampilkan panduan bagaimana cara memainkan Game Memory Training ini. Jika pemain memilih button play, maka ditampilkan dua pemilihan, antara ingin melakukan latihan (training) atau test. Untuk pemilihan test, terdapat Concentration atau Memory Test. Dimana Concentration Test ini mengacu pada form Wechsler dan Memory Test mengacu pada form IST, begitu juga untuk training. Jika pemain memilih Memory Test, maka muncul tampilan 5 kategori beserta 25 kata yang akan diingat oleh pemain selama 3 menit. Setelah 3 menit berakhir, maka 5 kategori yang berisikan 25 kata tersebut menghilang dan muncul pertanyaan sebanyak 20 pertanyaan yang harus diselesaikan oleh selama 18 detik untuk tiap soalnya (random).

Pemain memilih Concentration Test, maka akan menampilkan angka (0-9) yang jumlah items tiap angka pada soalnya berbedabeda. Tes ini terdapat 15 soal, terdiri dari pengacakan angka secara forward dan backward. Pada pengacakan angka secara forward, pengguna harus menyebutkan urutan deret angka dari depan ke belakang, sedangkan pada backward, pemain (siswa SMP) harus menyebutkan urutan deret angka dari belakang ke depan. Pada ConcentrationTest ini ditampilkan tester selama 10 detik untuk diingat oleh pemain, setelah itu tester tersebut ditutupidenganpalang. Palang baru dapat hilang jika angka pada 
urutan tertentu yang disebutkan oleh pemainbenar sesuai dengan keywords yang telah dimasukkan sebelumnya dan terdapat pada word library. Pemain memiliki waktu 30 detik untuk melafalkan kembali tester yang telah disebutkan untuk setiap soalnya.

Pemain memilih button training, maka pemain dihadapkan pemilihan buttontraining untuk Concentration atau MemoryTraining. Adapun output yang dihasilkan dari pemilihan training, yaitu record waktu terakhir pemain dalam menyelesaikan soal yang ada didalamnya. Disini, cara permainan untuk melakukan training sama dengan test, yang membedakannya hanya pada training tidak terdapat deteksi jawaban sebanyak 2 kali (harus menjawab sampai benar) dan sesuai dengan keywords yang telah didaftarkan sebelumnya, baru dapat melanjutkan ke soal atau items selanjutnya.

Terakhir yaitu menu result, dimana kita dapat melihat waktu training yang telah didapatkan oleh pemain dan disimpan pada game, kita juga dapat melihat nilai atau score test yang telah didapatkan dalam bentuk grafik. Jika nilai yang didapatkan oleh pemain lebih tinggi dari nilai sebelumnya, maka akan menampilkan tampilan "Congratulations, your Short Term Memory is Up !'. Selanjutnya, pemain mendapatkan nilai yang sama dari nilai yang sebelumnya, maka akan menampilkan tampilan "Good job, Keep improving your Short Term Memory
Skills". Terakhir, jika pemain mendapatkan nilai yang lebih rendah dari record nilai yang sebelumnya, maka akan menampilkan tampilan "Sorry, your Short Term Memory Skills is not good enough".

Waktu training dan score test yang dimuat didalam result, maksimal berjumlah 5 record hasil terakhir yang didapatkan oleh pemain (siswa SMP), jika hasil yang didapatkan dan disimpan lebih dari 5 record data (hasil), maka data (hasil) yang didapat oleh pemain diawal akan dihilangkan dan digantikan dengan data (hasil) yang terakhir didapatkan oleh pemain.

\section{PENGUJIAN DAN ANALISIS}

Adapun langkah-langkah atau tahapan pengerjaan yang dilakukan pada pembangunan Game Memory Training sebelum dilakukannya pengujian dan analisis data lebih lanjut dari hasil yang telah didapatkan, seperti berikut:

\subsection{Proses Desain Objek 2D Game Memory Training}

Pada proses desain objek angka dan palang berbentuk 2D, digunakan tools Blender dan Photoshop. Terdapat dua tahapan, yaitu yang pertama adalah membuat bentuk objek persegi pada Blender dan desain materials pada Photoshop.

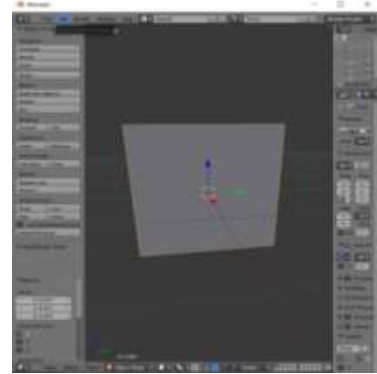

Gambar 5. Desain Objek 2D dengan Blender dan Photoshop
Tahapan berikutnya, pemberian materials pada objek persegi, seperti yang terlihat pada Gambar 6, kemudian dilakukan export

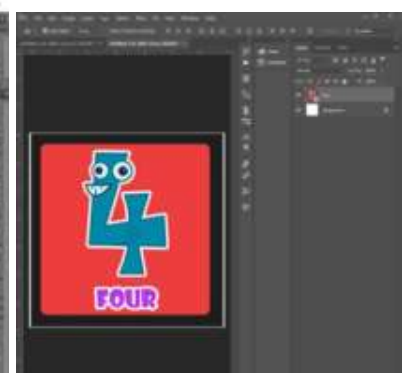

Autodesk FBX (.fbx) agar materials yang telah ditempelkan sebelumnya pada tools Blender dapat muncul pada Unity.

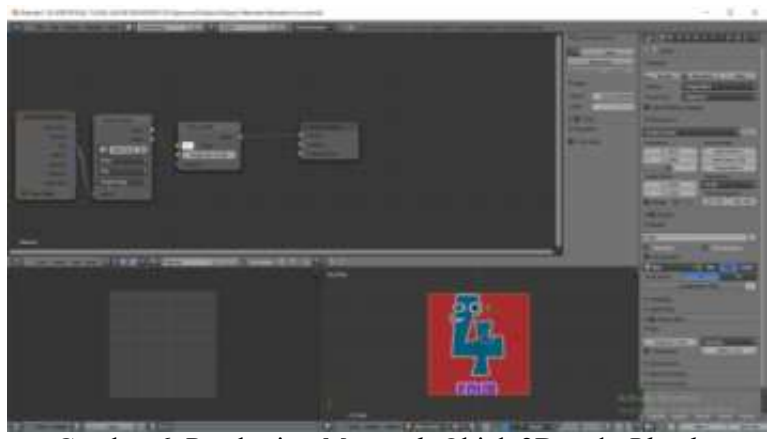

Gambar 6. Pemberian Materials Objek 2D pada Blender

\subsection{Pembangunan Sistem Game Memory Training}

Proses pembuatan Game Memory Training dengan Unity memiliki beberapa tahapan. Tahap pertama adalah membuat environment pada Unity yang menjadi scene atau wilayah kerja pada saat pembangunan game berlangsung. Scene atau wilayah kerja yang telah dilakukan pembangunan, nantinya akan dilakukan proses building hingga menjadi sebuah game pada akhirnya.

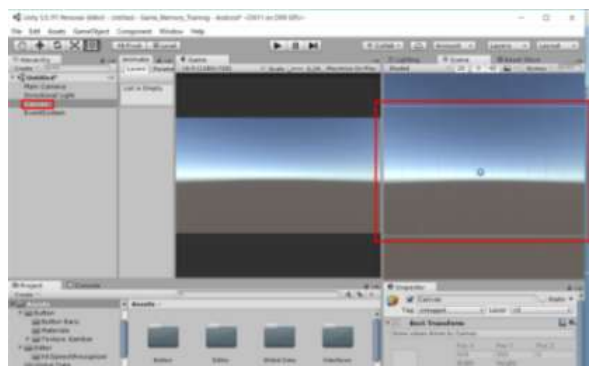

Gambar 7. Pembuatan Environment pada Game Memory Training 
Tahapan berikutnya adalah melakukan import objek 2D dan materials yang digunakan ke dalam asset game, seperti yang terlihat pada Gambar 8 dibawah ini.

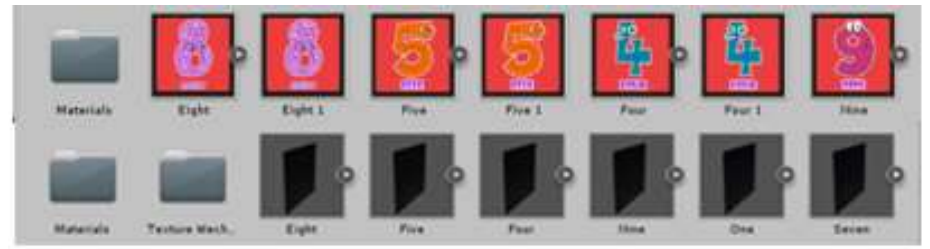

Gambar 8. Import objek 2D ke dalam Asset Unity

Selanjutnya, mengatur objek pada game yang dibangun didepan kamera. Posisi atau peletakan objek didepan kamera disesuaikan dengan kebutuhan atau desain yang ingin ditampilkan pada game.

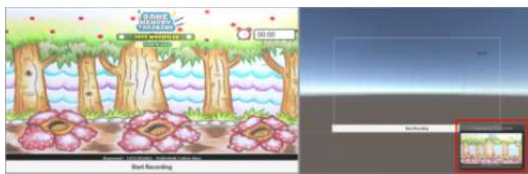

Gambar 9. Mengatur Objek didepan Kamera

Setelah itu, lakukan implementasi atau import coding speech recognition pada game yang dibangun. Pada pembangunan Game Memory Training ini menggunakan speech recognition dari asset Unity untuk Android. Gambar 10 merupakan folder asset yang digunakan untuk fitur speech recognition dengan nama folder KKSpeechRecognizer.

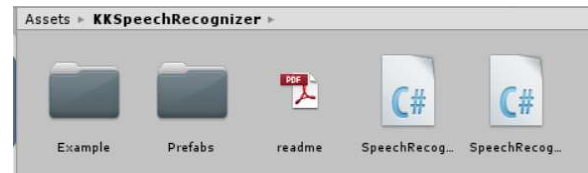

Gambar 10. Asset Unity untuk Speech Recognition pada Game

Pada Gambar 11 merupakan contoh scene pemberian kontrol untuk objek yang digunakan pada Concentration Test, yaitu pemain (siswa SMP) harus mengingat deret angka secara forward selama 10 detik, kemudian setelah melewati 10 detik, maka deret angka tersebut ditutupi dengan objek palang.

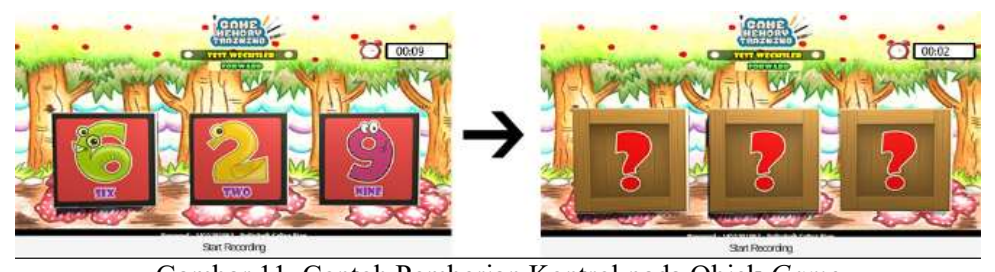

Gambar 11. Contoh Pemberian Kontrol pada Objek Game

Proses selanjutnya adalah build atau melakukan pembangunan game. Pilih scene yang diperlukan, kemudian pilih platform Android, karena game ini dibangun dengan menggunakan platform Android. Setelah melakukan pengaturan, kemudian tekan button Build And Run agar secara otomatis, game dapat berjalan pada Android setelah proses build selesai. Agar dapat memilih build as platform Android, sebelumnya pada menu Edit dibagian Preferences, kita harus memasukkan SDK dan JDK nya terlebih dahulu, kemudian tentukan tingkatan API, pada game ini dipilih tingkatan Android 4.4 Kit Kat (API level 19).

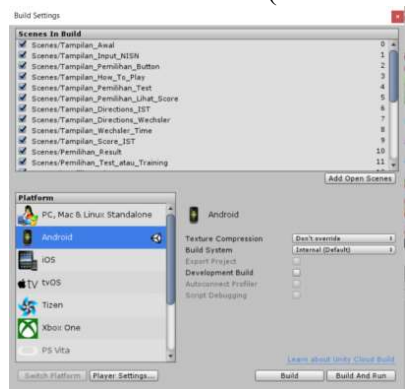

Gambar 4. 1 Build Game Memory Training

\subsection{Penerapan Aplikasi Game Memory Training}

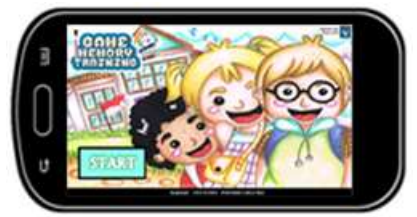

https://doi.org/10.25077/ TEKNOSI.v4i2.2018.061-072
Gambar 12. Tampilan Awal Game

Pada saat kita menjalankan game, terdapat tampilan button Start, untuk ke proses atau tampilan selanjutnya, pemain (siswa SMP) harus menekan button Start tersebut.

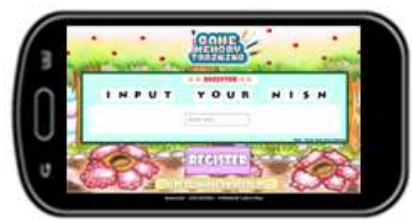

Gambar 13.Tampilan Register

Setelah menekan button Start, maka selanjutnya pemain (siswa SMP) memasuki scene register, dimana bagi siswa yang belum pernah memasuki Game Memory Training ini harus mendaftarkan NISN nya terlebih dahulu agar dapat memainkan Game Memory Training ini. Jika sudah pernah masuk sebelumnya, maka dapat melakukan proses login.

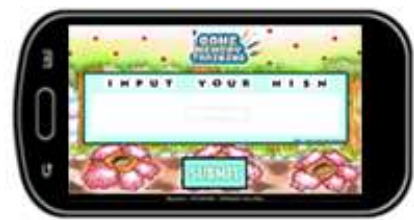

Gambar 14. Tampilan Login NISN

Gambar 14 merupakan tampilan login pada Game Memory Training ini, dimana pemain (siswa SMP) yang telah atau pernah 
masuk ke dalam Game Memory Training dapat langsung memilih dan melakukan input NISN pada scene login ini.

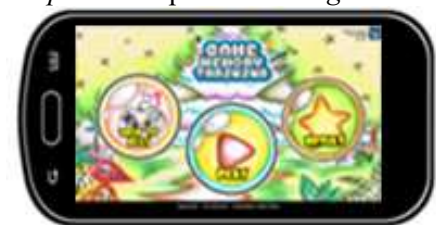

Gambar 15. Tampilan Pemilihan Menu

Pada tampilan pemilihan menu, terdapat 3 buah menu yang dapat kita pilih, yaitu menu how to play, play, dan result seperti terlihat pada gambar 15.

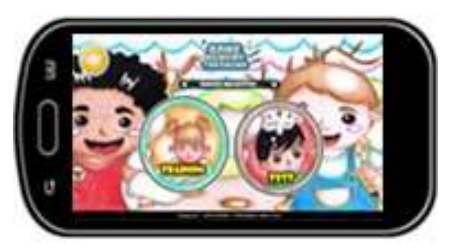

Gambar 16. Tampilan Pemilihan Play

Jika memilih menu play, maka terdapat pemilihan button training atau test, yang didalamnya terdapat permainan Concentration dan Memory yang mengacu pada form Wechsler dan IST.

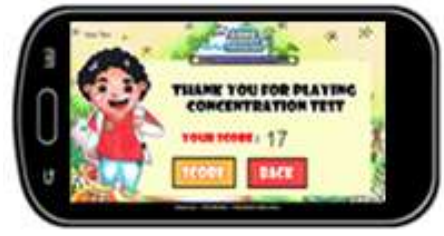

Gambar 17. Tampilan Score Game

Tampilan gambar 17 merupakan tampilan score akhir jika telah memainkan Concentration Test. Jika kita menekan button score maka memunculkan visualisasi score yang didapatkan dalam bentuk grafik dan jika menekan button Back maka kembali ke menu home.

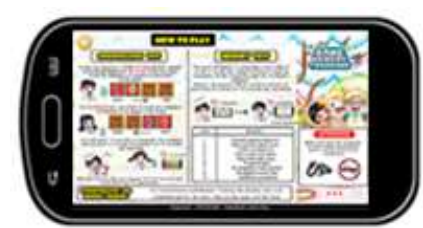

Gambar 18. Tampilan How To Play

Tampilan How To Play pada gambar 18 berisikan panduan permainan Game Memory Training yang telah dibangun.

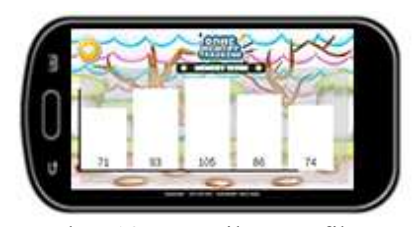

Gambar 19. Tampilan Grafik Memory Test

Gambar 19 merupakan tampilan visualisasi melalui grafik pada score yang didapatkan oleh pemain (siswa SMP) dalam memainkan Memory Test, begitu juga untuk Concentration Test.

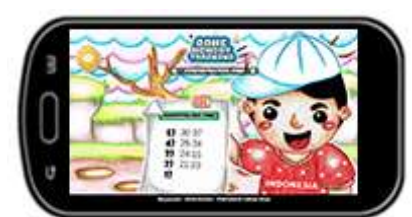

Gambar 20. Tampilan Record Waktu Concentration Training

Pada Gambar 20 merupakan tampilan record waktu atau durasi lamanya pemain (siswa SMP) dalam melakukan latihan atau training pada Concentration dan Memory Training.

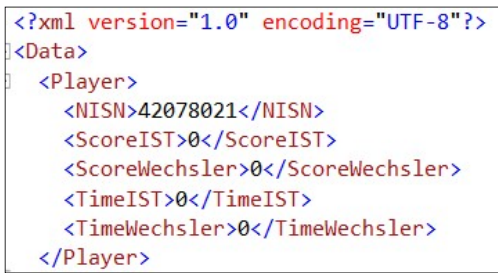

Gambar 21. Struktur XML Game Memory Training

Pada Gambar 21 merupakan tampilan dari struktur $X M L$ yang digunakan pada pembangunan Game Memory Training ini, terdiri dari NISN, score IST, score Wechsler, time IST, dan time Wechsler.

\subsection{Hasil Pengujian dan Analisa}

\subsubsection{Blackbox Test Case}

Pengujian testcase dilakukan dengan Ibu Dra.Erni Yulial,S.Psi. selaku psikolog klinis untuk menguji fungsi-fungsi yang ada pada game untuk mengetahui apakah game yang telah dibangun dapat berjalan sesuai dengan output yang diharapkan. Secara keseluruhan, dari hasil pengujian blackbox dengan menggunakan testcase, dapat disimpulkan bahwa fungsi yang terdapat pada Game Memory Training dapat berjalan 100\% sesuai dengan output yang diharapkan.

\subsubsection{Pengumpulan Data}

\subsubsection{Metode Wawancara}

Pengujian menggunakan metode wawancara dilakukan dengan Ibu Dra. Erni Yulial, S.Psi. selaku psikolog klinis, didapat bahwa Game Memory Training yang telah dibangun dapat membantu meningkatkan kemampuan Short Term Memory (STM) para siswa, karena pada game ini siswa diminta untuk mengingat atau melafalkan kembali deret angka yang susunannya forward dan backward. Tidak hanya itu, siswa juga diminta untuk mengingat 5 kategori dan 25 kata, kemudian diuji kembali sesuai dengan ketentuan yang telah mengacu pada form IST dan Wechsler Intelligence Bellevue. Adapun catatan tambahan pada pengujian ini adalah nama "IST Test" yang terdapat pada game sebaiknya diganti menjadi "Memory Test" dan "Wechsler Test" diganti menjadi "Concentration Test", begitu juga dengan training, karena hal ini berkaitan dengan privasi dan kode etik pada bidang psikologi (harus menjamin kerahasiaan bentuk test). Kemudian, dengan tidak memberikan musik latar pada pemain (siswa SMP) saat mengingat materi pada Memory Training dan Test sudah tepat, karena dapat mempengaruhi daya konsentrasi para siswa, terutama musik dengan aliran rock dan metal. Untuk perhitungan jumlah butir soal yang benar pada saat memainkan Memory Test dan Concentration Test untuk dijadikan score akhir telah sesuai dan telah mengacu pada form IST dan Wechsler Intelligence 
Bellevue, lamanya durasi, aturan pengerjaan test dan training sudah tepat.

\subsubsection{Metode Tes}

Adapun pengujian yang dilakukan dengan menggunakan metode tes untuk melihat peningkatan Short Term Memory (STM), seperti :

1. Dilakukan pre-test pada siswa SMP Dharma Loka Pekanbaru dengan menggunakan soal (kertas) yang telah disepakati dengan Ibu Dra. Erni Yulial, S.Psi. untuk mendapatkan nilai awal para peserta didik yang terkait dengan pengujian.

2. Selanjutnya, diberikan Game Memory Training yang telah dibangun kepada peserta didik SMP Dharma Loka Pekanbaru yang terkait pengujian untuk melihat peningkatan Short Term Memory (STM).

3. Kemudian, dilihat apakah adanya peningkatan memori jangka pendek peserta didik SMP Dharma Loka Pekanbaru yang terlibat didalam penelitian dengan cara membandingkan nilai atau hasil yang didapat pada soal (kertas) yang diberikan pada saat pre-test dengan nilai yang didapatkan pada tes akhir (dengan soal yang sama).

4. Dapat dilihat juga peningkatan Short Term Memory (STM) dari record score dan waktu menyelesaikan permainan pada Game Memory Training yang telah dimainkan oleh pengguna.

Tabel 1. Perbandingan Nilai Pre-Test dengan Test Akhir

\begin{tabular}{|c|c|c|c|c|c|c|c|}
\hline \multirow[t]{2}{*}{ No } & \multirow[t]{2}{*}{ Nama Peserta Didik } & \multicolumn{3}{|c|}{ Memory Test (IST) } & \multicolumn{3}{|c|}{ Concentration Test (Wechsler) } \\
\hline & & $\begin{array}{c}\text { Pre- } \\
\text { Test } \\
\text { Awal }\end{array}$ & $\begin{array}{c}\text { Test } \\
\text { Akhir }\end{array}$ & Keterangan & $\begin{array}{l}\text { Pre- } \\
\text { Test } \\
\text { Awal }\end{array}$ & $\begin{array}{c}\text { Test } \\
\text { Akhir }\end{array}$ & Keterangan \\
\hline 1 & $\begin{array}{l}\text { ALESSANDRA } \\
\text { VALENTINA }\end{array}$ & 115 & 115 & Tetap & 10 & 7 & Menurun \\
\hline 2 & AVERINA SURYA & 86 & 110 & Meningkat & 13 & 8 & Menurun \\
\hline 3 & $\begin{array}{l}\text { BECKHAM } \\
\text { RONALDLIE }\end{array}$ & 93 & 115 & Meningkat & 7 & 8 & Meningkat \\
\hline 4 & CAROLINA ONG & 117 & 120 & Meningkat & 5 & 10 & Meningkat \\
\hline 5 & $\begin{array}{l}\text { CHRISTOPHER } \\
\text { WILLIAM }\end{array}$ & 91 & 103 & Meningkat & 8 & 8 & Tetap \\
\hline 6 & CINTHIA & 105 & 115 & Meningkat & 5 & 7 & Meningkat \\
\hline 7 & $\begin{array}{l}\text { DAUD } \\
\text { MARKHESYWAN } \\
\text { MANASSE }\end{array}$ & 100 & 105 & Meningkat & 7 & 7 & Tetap \\
\hline 8 & DESATA BERTU & 100 & 103 & Meningkat & 8 & 8 & Tetap \\
\hline 9 & ENGELLIM & 93 & 117 & Meningkat & 10 & 8 & Menurun \\
\hline 10 & FLAVIA EMMELINE & 113 & 117 & Meningkat & 13 & 12 & Menurun \\
\hline 11 & $\begin{array}{l}\text { GRACELLA } \\
\text { MARGARETHA }\end{array}$ & 103 & 103 & Tetap & 8 & 14 & Meningkat \\
\hline 12 & IRVAN ELLIM & 100 & 120 & Meningkat & 13 & 14 & Meningkat \\
\hline 13 & JACKY & 95 & 120 & Meningkat & 14 & 14 & Tetap \\
\hline 14 & JONATHAN YAP & 110 & 120 & Meningkat & 7 & 15 & Meningkat \\
\hline 15 & JULIA & 76 & 98 & Meningkat & 12 & 17 & Meningkat \\
\hline 16 & JUNITA ANGELINA & 113 & 117 & Meningkat & 5 & 10 & Meningkat \\
\hline 17 & KARIN SAPUTRA & 115 & 120 & Meningkat & 8 & 10 & Meningkat \\
\hline 18 & KARYN PATRISIA & 91 & 108 & Meningkat & 7 & 10 & Meningkat \\
\hline 19 & KELLY ANGELINE & 98 & 120 & Meningkat & 7 & 10 & Meningkat \\
\hline 20 & $\begin{array}{l}\text { MARSELLA TAN } \\
\text { NUSA }\end{array}$ & 98 & 100 & Meningkat & 3 & 5 & Meningkat \\
\hline 21 & MELISSA & 83 & 108 & Meningkat & 7 & 8 & Meningkat \\
\hline 22 & $\begin{array}{l}\text { MELLYANA } \\
\text { WULANDARI }\end{array}$ & 91 & 108 & Meningkat & 5 & 8 & Meningkat \\
\hline 23 & NOVIANTI & 105 & 113 & Meningkat & 12 & 13 & Meningkat \\
\hline 24 & $\begin{array}{l}\text { RIVALDO } \mathrm{H} \text {. } \\
\text { PRATAMA }\end{array}$ & 88 & 108 & Meningkat & 10 & 12 & Meningkat \\
\hline 25 & $\begin{array}{l}\text { PRAIAMA } \\
\text { SELVY }\end{array}$ & 100 & 117 & Meningkat & 7 & $\frac{12}{8}$ & Meningkat \\
\hline 26 & $\begin{array}{l}\text { SHELVI OCTAVIA } \\
\text { ANDREAS }\end{array}$ & 100 & 110 & Meningkat & 12 & 12 & Tetap \\
\hline 27 & SHELVINA WIJAYA & 83 & 110 & Meningkat & 10 & 14 & Meningkat \\
\hline 28 & STEVEN HUTOMO & 81 & 103 & Meningkat & 7 & 12 & Meningkat \\
\hline 29 & STEVEN LIEM & 105 & 120 & Meningkat & 7 & 10 & Meningkat \\
\hline 30 & VICTOR UTAMA & 98 & 117 & Meningkat & 7 & 8 & Meningkat \\
\hline 31 & WILLIAM & 91 & 95 & Meningkat & 7 & 8 & Meningkat \\
\hline 32 & $\begin{array}{l}\text { WILLIAM } \\
\text { ANDFRSN }\end{array}$ & & & Meningkat & 8 & & Meningkat \\
\hline 33 & $\begin{array}{l}\text { ANDERSEN } \\
\text { WINNIE ANGELINA }\end{array}$ & $\frac{113}{108}$ & $\frac{117}{120}$ & $\begin{array}{l}\text { Meningkat } \\
\text { Meningkat }\end{array}$ & $\frac{8}{8}$ & $\frac{14}{7}$ & Menurun \\
\hline
\end{tabular}

Dari hasil pengolahan Tabel 4.1Perbandingan Nilai Pre-Test dengan Test Akhir, dapat dilihat perbandingan nilai pre-test awal dengan akhir Memory Test yang mengacu pada form IST sebanyak 31 siswa atau setara dengan $93,9 \%$ dari total keseluruhan siswa yang terkait pengujian mengalami peningkatan pada nilai akhir yang didapat dari sebelumnya dan 2 orang siswa tidak mengalami peningkatan maupun penurunan (tetap). Kemudian, pada Concentration Test yang mengacu pada form Wechsler sebanyak 23 siswa atau setara dengan $69,7 \%$ dari total keseluruhan siswa yang terkait pengujian mengalami peningkatan pada nilai akhir yang didapat dari sebelumnya, 5 orang siswa mengalami penurunan, dan sisanya tidak mengalami peningkatan maupun penurunan (tetap). Visualisasi dalam bentuk grafik hasil perbandingan pengujian tes awal dengan akhir, dapat dilihat pada grafik dibawah ini.

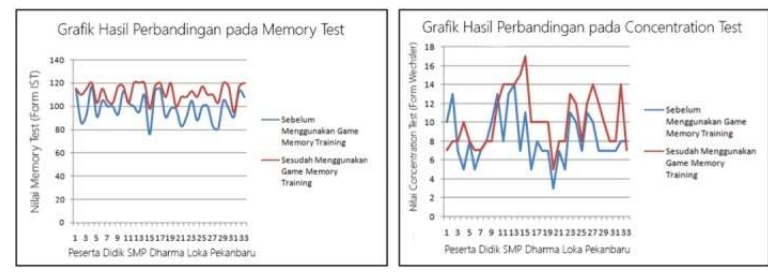

Gambar 4.19 Grafik Hasil Perbandingan Pengujian Pre-Test dengan Test Akhir

Pada Gambar 4.19 merupakan hasil perbandingan pengujian pada Memory Test dan Concentration Test yang divisualisasikan dalam bentuk grafik berdasarkan perbandingan nilai pre-test awal dengan tes akhir yang didapatkan oleh siswa SMP Dharma Loka Pekanbaru yang terkait dengan pengujian pada Tabel 4.1 diatas. Dapat dilihat, grafik yang memiliki garis (line) berwarna biru menandakan nilai yang didapatkan oleh peserta didik sebelum menggunakan Game Memory Training dan grafik yang memiliki garis (line) berwarna merah menandakan nilai yang didapatkan oleh peserta didik setelah menggunakan Game Memory Training.

Peningkatan Short Term Memory (STM) juga dapat dilihat pada record score dan waktu yang didapatkan oleh para pemain (siswa SMP), dari 5 score akhir dan waktu yang tersimpan pada Android, dimana sebagian besar siswa mendapatkan score akhir dan lama durasi pengerjaan (waktu terakhir yang tercatat) dengan hasil yang bersifat fluktuasi (naik turun). Kondisi tersebut juga dipengaruhi oleh pronounciation para siswa dalam melakukan input jawaban berupa suara dalam Bahasa Inggris pada game ini. Berdasarkan hasil pengolahan kuisioner yang telah diberikan sebelumnya kepada 33 siswa untuk mengetahui keywords pada Game yang sulit dideteksi, didapatkan dalam mengerjakan soal Concentration, keywords yang paling sulit untuk dideteksi sehingga mempengaruhi score dan durasi pengerjaan pada game yaitu "two", "four", "three", dan "eight". Pada pengerjaan soal Memory, keywords yang paling sulit untuk dideteksi yaitu "vase", "scissors", "noun", dan "fruit", hal ini terkait dengan adanya perbedaan penulisan dengan cara pengucapan dalam bahasa Inggris ketika dilafalkan dan tidak semua peserta didik memiliki pronounciation yang baik.

Analisa hasil dari perbandingan nilai yang didapatkan oleh para siswa pada saat melakukan pre-test dengan test akhir, yaitu pada saat memainkan Game Memory Training, pronounciation juga mempengaruhi nilai dan durasi pengerjaan para siswa, karena tidak semua siswa memiliki pronounciation dalam Bahasa Inggris yang baik, memainkan Game Memory Training pada tempat yang memiliki tingkat kebisingan (noise) yang tinggi dan dilakukan pada jarak yang terlalu dekat dan jauh juga mempengaruhi nilai dan waktu yang didapatkan oleh pemain, karena hal ini terkait dengan pendeteksian keywords menggunakan speech recognition sebagai media input jawaban, ada atau tidaknya asupan makanan, minuman, dan obat-obatan yang dikonsumsi oleh siswa sebelum melakukan pengujian dan memainkan Game Memory Training ini juga dapat mempengaruhi nilai yang didapatkan, karena hal ini berhubungan dengan tingkat konsentrasi para siswa, mengkonsumsi obatobatan tertentu dapat menyebabkan kantuk dan tingkat konsentrasi menurun pada pemain (siswa SMP).

\subsubsection{Uji Speech Recognition}

\subsubsection{Performa pada Ketepatan Keywords}

Pengujian suara untuk sistem speech recognition ini dilakukan untuk mengetahui bahwa speech recognition dapat 
menangkap keywords yang telah diatur dalam game. Keywords yang telah diatur dalam game antara lain:

Tabel 2. Keywords pada Concentration Test dan Training

\begin{tabular}{|c|c|l|}
\hline No & Keywords & \multicolumn{1}{|c|}{ Fungsi } \\
\hline 1 & One & Membuka palang yang berisi jawaban keyword "One" \\
\hline 2 & Two & Membuka palang yang berisi jawaban keyword "Two" \\
\hline 3 & Three & Membuka palang yang berisi jawaban keyword "Three" \\
\hline 4 & Four & Membuka palang yang berisi jawaban keyword "Four" \\
\hline 5 & Five & Membuka palang yang berisi jawaban keyword "Five" \\
\hline 6 & Six & Membuka palang yang berisi jawaban keyword "Six" \\
\hline 7 & Seven & Membuka palang yang berisi jawaban keyword "Seven" \\
\hline 8 & Eight & Membuka palang yang berisi jawaban keyword "Eight" \\
\hline 9 & Nine & Membuka palang yang berisi jawaban keyword "Nine" \\
\hline
\end{tabular}

Tabel 3. Keywords pada Memory Test dan Training

\begin{tabular}{|c|c|c|c|}
\hline No & Kategori & $\begin{array}{c}\text { Keywords soal } \\
\text { Memory }\end{array}$ & Fungsi \\
\hline 1 & Animal & Eagle & Untuk menjawab soal berawalan kata "E" \\
\hline & & Fish & Untuk menjawab soal berawalan kata "F" \\
\hline & & Horse & Untuk menjawab soal berawalan kata "H" \\
\hline & & Wolf & Untuk menjawab soal berawalan kata "W" \\
\hline & & Zebra & Untuk menjawab soal berawalan kata "Z" \\
\hline 2 & Color & Blue & Untuk menjawab soal berawalan kata "B" \\
\hline & & Cream & Untuk menjawab soal berawalan kata "C" \\
\hline & & Green & Untuk menjawab soal berawalan kata "G" \\
\hline & & Maroon & Keyword ini tidak diikut sertakan dalamjawaban \\
\hline & & Yellow & Untuk menjawab soal berawalan kata "Y" \\
\hline 3 & Fruit & Apple & Untuk menjawab soal berawalan kata "A" \\
\hline & & Durian & Untuk menjawab soal berawalan kata "D" \\
\hline & & Kiwi & Untuk menjawab soal berawalan kata "K" \\
\hline & & Lemon & Untuk menjawab soal berawalan kata "L" \\
\hline & & Orange & Untuk menjawab soal berawalan kata "O" \\
\hline \hline 4 & Noun & Iron & Untuk menjawab soal berawalan kata "I" \\
\hline & & Jacket & Untuk menjawab soal berawalan kata "J" \\
\hline & & Ulna & Keyword ini tidak diikut sertakan dalamjawaban \\
\hline & & Vase & Untuk menjawab soal berawalan kata "V" \\
\hline & & X-Ray & Keyword ini tidak diikut sertakan dalamjawaban \\
\hline 5 & Stationary & Notebook & Untuk menjawab soal berawalan kata "N" \\
\hline & & Pencil & Untuk menjawab soal berawalan kata "P" \\
\hline & & Ruler & Keyword ini tidak diikut sertakan dalamjawaban \\
\hline & & Scissors & Untuk menjawab soal berawalan kata "S" \\
\hline & & Textbook & Untuk menjawab soal berawalan kata "T" \\
\hline
\end{tabular}

Tabel 4. Keywords Kategori pada Memory Test dan Training

\begin{tabular}{|c|c|c|}
\hline No & Kategori & Fungsi \\
\hline 1 & Animal & Untuk menjawab soal yang tergolong pada kategori "Animal" \\
\hline 2 & Color & Untuk menjawab soal yang tergolong pada kategori "Color" \\
\hline 3 & Fruit & Untuk menjawab soal yang tergolong pada kategori "Fruit" \\
\hline 4 & Noun & Untuk menjawab soal yang tergolong pada kategori "Noun" \\
\hline 5 & Stationary & Untuk menjawab soal yang tergolong pada kategori "Stationary" \\
\hline
\end{tabular}

1. Pengujian Keywords

Pengujian ini dilakukan dengan tujuan untuk mengetahui bahwa keywords yang telah diatur dapat bekerja sesuai dengan kebutuhan.

Tabel 5. Keywords pada Concentration Test dan Training

\begin{tabular}{|l|l|l|}
\hline No & Keywords & Keterangan \\
\hline 1 & One & Berfungsi \\
\hline 2 & Two & Berfungsi \\
\hline 3 & Three & Berfungsi \\
\hline 4 & Four & Berfungsi \\
\hline 5 & Five & Berfungsi \\
\hline 6 & Six & Berfungsi \\
\hline 7 & Seven & Berfungsi \\
\hline 8 & Eight & Berfungsi \\
\hline 9 & Nine & Berfungsi \\
\hline
\end{tabular}

Banyak keywords: 9

Jumlah keywords yang ditangkap: 9

Presentasi keakuratan: 100\%
Tabel 6. Keywords pada Memory Test dan Training

\begin{tabular}{|c|c|c|c|}
\hline No & Kategori & Keywords & Keterangan \\
\hline 1 & Animal & Eagle & Berfungsi \\
\hline 2 & & Fish & Berfungsi \\
\hline 3 & & Horse & Berfungsi \\
\hline 4 & & Wolf & Berfungsi \\
\hline 5 & & Zebra & Berfungsi \\
\hline 6 & Noun & Iron & Berfungsi \\
\hline 7 & & Jacket & Berfungsi \\
\hline 8 & & Vase & Berfungsi \\
\hline 9 & Frnit & Apple & Berfungsi \\
\hline 10 & & Durian & Berfungsi \\
\hline 11 & & Kiwi & Berfungsi \\
\hline 12 & & Lemon & Berfungsi \\
\hline 13 & & Orange & Berfungsi \\
\hline 14 & Stationary & Notebook & Berfungsi \\
\hline 15 & & Pencil & Berfungsi \\
\hline 16 & & Scissors & Berfungsi \\
\hline 17 & & Textbook & Berfungsi \\
\hline 18 & Color & Blue & Berfungsi \\
\hline 19 & & Cream & Berfungsi \\
\hline 20 & & Green & Berfungsi \\
\hline 21 & & Yellow & Berfungsi \\
\hline
\end{tabular}

Banyak keywords: 21

Jumlah keywords yang ditangkap: 21

Presentasi keakuratan: $100 \%$

Tabel 7. Keywords Kategori pada Memory Test dan Training

\begin{tabular}{|l|l|l|}
\hline No & Keywords & \multicolumn{1}{|c|}{ Keterangan } \\
\hline 1 & Animal & $\begin{array}{l}\text { Untuk menjawab soal yang memiliki } \\
\text { jawaban kategori "Animal" }\end{array}$ \\
\hline 2 & Color & $\begin{array}{l}\text { Untuk menjawab soal yang memiliki } \\
\text { jawaban kategori "Color" }\end{array}$ \\
\hline 3 & Fruit & $\begin{array}{l}\text { Untuk menjawab soal yang memiliki } \\
\text { jawaban kategori "Fruif" }\end{array}$ \\
\hline 4 & Noun & $\begin{array}{l}\text { Untuk menjawab soal yang memiliki } \\
\text { jawaban kategori "Noun" }\end{array}$ \\
\hline 5 & Stationary & $\begin{array}{l}\text { Untuk menjawab soal yang memiliki } \\
\text { iawaban kategori "Stationary" }\end{array}$ \\
\hline
\end{tabular}

Banyak keywords: 5

Jumlah keywords yang ditangkap: 5

Presentasi keakuratan: $100 \%$

2. Pengujian pada saat suasana sunyi tanpa menggunakan microphone.

Pengujian pada saat suasana sunyi dilakukan pada ruangan yang memiliki tingkat noise sebesar $31 \mathrm{~dB}$. Pengujian ini dilakukan dengan tujuan untuk mengetahui bahwa keywords yang telah diatur dapat ditangkap dengan baik oleh game saat suasana sunyi tanpa menggunakan microphone.

Tabel 8 Pengujian Suasana Sunyi tanpa Microphone

\begin{tabular}{|c|c|c|c|c|c|c|c|c|}
\hline \multicolumn{7}{|c|}{ Concentration Test dan Training } & \multicolumn{6}{c|}{ Memory Test dan Training } \\
\hline No & Keywords & Keterangan & No & Keywords & Keterangan & No & Keywords & Keterangan \\
\hline 1 & One & Berfungsi & 1 & Animal & Berfungsi & 14 & Durian & Berfungsi \\
\hline 2 & Two & Berfungsi & 2 & Eagle & Berfungsi & 15 & Kiwi & Berfungsi \\
\hline 3 & Three & Berfungsi & 3 & Fish & Berfungsi & 16 & Lemon & Berfungsi \\
\hline 4 & Four & Berfungsi & 4 & Horse & Berfungsi & 17 & Orange & Berfungsi \\
\hline 5 & Five & Berfungsi & 5 & Wolf & Berfungsi & 18 & Noun & Berfungsi \\
\hline 6 & Six & Berfungsi & 6 & Zebra & Berfungsi & 19 & Iron & Berfungsi \\
\hline 7 & Seven & Berfungsi & 7 & Color & Berfungsi & 20 & Jacket & Berfungsi \\
\hline 8 & Eight & Berfungsi & 8 & Blue & Berfungsi & 21 & Vase & Berfungsi \\
\hline 9 & Nine & Berfungsi & 9 & Cream & Berfungsi & 22 & Stationary & Berfungsi \\
\hline \multirow{6}{*}{} & 10 & Green & Berfungsi & 23 & Notebook & Berfungsi \\
\cline { 3 - 9 } & 11 & Yellow & Berfungsi & 24 & Pencil & Berfungsi \\
\cline { 3 - 9 } & 12 & Fruit & Berfungsi & 25 & Scissors & Berfungsi \\
\cline { 3 - 9 } & 13 & Apple & Berfungsi & 26 & Textbook & Berfungsi \\
\hline
\end{tabular}

Banyak keywords: 35

Jumlah keywords yang ditangkap: 35

Presentasi keakuratan: $100 \%$ 
3. Pengujian pada saat suasana ramai tanpa menggunakan microphone

Pengujian pada saat suasana ramai dilakukan pada ruangan yang memiliki tingkat kebisingan (noise) sebesar $53 \mathrm{~dB}$ (desibel). Pengujian ini dilakukan dengan tujuan untuk mengetahui bahwa keywords yang telah diatur dapat ditangkap oleh game saat suasana ramai tanpa menggunakan microphone.

Tabel 9. Pengujian Suasana Ramai tanpa Microphone

\begin{tabular}{|c|c|c|c|c|c|c|c|c|}
\hline \multicolumn{3}{|c|}{ Concentration Test dan Training } & \multicolumn{6}{|c|}{ Memory Test dan Training } \\
\hline No & Keywords & Keterangan & No & Keywords & Keterangan & No & Keywords & Keterangan \\
\hline 1 & One & Berfungsi & 1 & Animal & Gagal & 14 & Durian & Gagal \\
\hline 2 & Two & Gagal & 2 & Eagle & Gagal & 15 & Kiwi & Gagal \\
\hline 3 & Three & Gagal & 3 & Fish & Gagal & 16 & Lemon & Gagal \\
\hline 4 & Four & Gagal & 4 & Horse & Gagal & 17 & Orange & Berfungsi \\
\hline 5 & Five & Gagal & 5 & Wolf & Berfungsi & 18 & Noun & Gagal \\
\hline 6 & Six & Gagal & 6 & Zebra & Gagal & 19 & Iron & Gagal \\
\hline 7 & Seven & Gagal & 7 & Color & Gagal & 20 & Jacket & Gagal \\
\hline 8 & Eight & Gagal & 8 & Blue & Berfungsi & 21 & Vase & Gagal \\
\hline 9 & Nine & Berfungsi & 9 & Cream & Gagal & 22 & Stationary & Gagal \\
\hline & & & 10 & Green & Berfungsi & 23 & Notebook & Gagal \\
\hline & & & 11 & Yellow & Berfungsi & 24 & Pencil & Gagal \\
\hline & & & 12 & Fruit & Gagal & 25 & Scissors & Gagal \\
\hline & & & 13 & Apple & Berfungsi & 26 & Textbook & Gagal \\
\hline
\end{tabular}

Banyak keywords: 35

Jumlah keywords yang ditangkap: 8

Presentasi keakuratan: 22,86\%

4. Pengujian pada saat suasana sunyi dengan microphone Pengujian pada saat suasana sunyi dilakukan pada ruangan yang memiliki tingkat noise sebesar $31 \mathrm{~dB}$ (desibel). Pengujian ini dilakukan dengan tujuan untuk mengetahui bahwa keywords yang telah diatur dapat ditangkap dengan baik oleh game saat suasana sunyi dengan menggunakan microphone.

Tabel 10. Pengujian Suasana Sunyi dengan Microphone

\begin{tabular}{|c|c|c|c|c|c|c|c|c|}
\hline \multicolumn{3}{|c|}{ Concentration Test dan Training } & \multicolumn{6}{|c|}{ Memory Test dan Training } \\
\hline No & Keywords & Keterangan & No & Keywords & Keterangan & No & Keywords & Keterangan \\
\hline 1 & One & Berfungsi & 1 & Animal & Berfungsi & 14 & Durian & Berfungsi \\
\hline 2 & Two & Berfungsi & 2 & Eagle & Berfungsi & 15 & Kiwi & Berfungsi \\
\hline 3 & Three & Berfungsi & 3 & Fish & Berfungsi & 16 & Lemon & Berfungsi \\
\hline 4 & Four & Berfungsi & 4 & Horse & Berfungsi & 17 & Orange & Berfungsi \\
\hline 5 & Five & Berfungsi & 5 & Wolf & Berfungsi & 18 & Noun & Berfungsi \\
\hline 6 & Six & Berfungsi & 6 & Zebra & Berfungsi & 19 & Iron & Berfungsi \\
\hline 7 & Seven & Berfungsi & 7 & Color & Berfungsi & 20 & Jacket & Berfungsi \\
\hline 8 & Eight & Berfungsi & 8 & Blue & Berfungsi & 21 & Vase & Berfungsi \\
\hline 9 & Nine & Berfungsi & 9 & Cream & Berfungsi & 22 & Stationary & Berfungsi \\
\hline & & & 10 & Green & Berfungsi & 23 & Notebook & Berfungsi \\
\hline & & & 11 & Yellow & Berfungsi & 24 & Pencil & Berfungsi \\
\hline & & & 12 & Fruit & Berfungsi & 25 & Scissors & Berfungsi \\
\hline & & & 13 & Apple & Berfungsi & 26 & Textbook & Berfungsi \\
\hline
\end{tabular}

Banyak keywords: 35

Jumlah keywords yang ditangkap: 35

Presentasi keakuratan: $100 \%$

5. Pengujian pada saat suasana ramai dengan microphone Pengujian pada saat suasana ramai dilakukan di ruangan yang memiliki tingkat kebisingan (noise) sebesar $53 \mathrm{~dB}$ (desibel). Pengujian ini dilakukan dengan tujuan untuk mengetahui bahwa keywords yang telah diatur dapat ditangkap dengan baik oleh game saat suasana ramai dengan menggunakan microphone.

Tabel 11. Pengujian Suasana Ramai dengan Microphone

\begin{tabular}{|c|c|c|c|c|c|c|c|c|}
\hline \multicolumn{3}{|c|}{ Concentration Test dan Training } & \multicolumn{6}{|c|}{ Memory Test dan Training } \\
\hline No & Keywords & Keterangan & No & Keywords & Keterangan & No & Keywords & Keterangan \\
\hline 1 & One & Berfungsi & 1 & Animal & Gagal & 14 & Durian & Gagal \\
\hline 2 & Two & Gagal & 2 & Eagle & Gagal & 15 & Kiwi & Gagal \\
\hline 3 & Three & Gagal & 3 & Fish & Gagal & 16 & Lemon & Berfungsi \\
\hline 4 & Four & Gagal & 4 & Horse & Berfungsi & 17 & Orange & Berfungsi \\
\hline 5 & Five & Berfungsi & 5 & Wolf & Berfungsi & 18 & Noun & Gagal \\
\hline 6 & Six & Gagal & 6 & Zebra & Gagal & 19 & Iron & Gagal \\
\hline 7 & Seven & Berfungsi & 7 & Color & Gagal & 20 & Jacket & Gagal \\
\hline 8 & Eight & Gagal & 8 & Blue & Berfungsi & 21 & Vase & Gagal \\
\hline \multirow[t]{5}{*}{9} & Nine & Berfungsi & 9 & Cream & Gagal & 22 & Stationary & Gagal \\
\hline & & & 10 & Green & Berfungsi & 23 & Notebook & Gagal \\
\hline & & & 11 & Yellow & Berfungsi & 24 & Pencil & Berfungsi \\
\hline & & & 12 & Fruit & Gagal & 25 & Scissors & Gagal \\
\hline & & & 13 & Apple & Berfungsi & 26 & Textbook & Gagal \\
\hline
\end{tabular}

Banyak keywords: 35

Jumlah keywords yang ditangkap: 13

Presentasi keakuratan: $37,14 \%$

Analisa hasil pada pengujian yang telah dilakukan yaitu, saat memainkan game pada suasana yang ramai, penggunaan microphone dalam menangkap suara pada Game Memory Training lebih baik, dibandingkan tanpa menggunakan microphone, karena hal ini berkaitan dengan tingkat kebisingan (noise) pada saat memainkan Game Memory Training, semakin rendah tingkat kebisingan (noise) pada suatu tempat, maka pendeteksian keywords akan semakin akurat dibandingkan memainkan Game Memory Training ini pada tempat yang memiliki tingkat kebisingan (noise) yang tinggi.

\subsubsection{Performa pada Jarak}

Pengujian performa speech recognition berdasarkan jarak ini menggunakan perangkat Android milik Penulis dan dilakukan pada ruangan yang memiliki tingkat kebisingan (noise) sebesar $31 \mathrm{~dB}$ (lemah), $56 \mathrm{~dB}$ (sedang), dan $71 \mathrm{~dB}$ (keras) tanpa menggunakan microphone.

Tabel 12. Uji Performa Speech Recognition pada Jarak

\begin{tabular}{|c|c|c|c|c|c|c|c|c|c|c|}
\hline \multirow[t]{2}{*}{ No. } & \multirow{2}{*}{ Kategon } & \multicolumn{9}{|c|}{ jak (cm) } \\
\hline & & $\infty-3$ & ${ }_{20}^{40}$ & $\begin{array}{l}21 . \\
60\end{array}$ & $\begin{array}{l}61- \\
100\end{array}$ & $\begin{array}{l}101- \\
140\end{array}$ & $\begin{array}{l}141 . \\
180\end{array}$ & $\begin{array}{l}181 . \\
220\end{array}$ & $\begin{array}{l}221- \\
250\end{array}$ & $\rightarrow 250$ \\
\hline 1 & $31 \mathrm{~dB}$ & $\mathrm{x}$ & $\varnothing$ & $\varnothing$ & $\varnothing$ & $\varnothing$ & $\varnothing$ & $\varnothing$ & $\infty$ & $x$ \\
\hline 2 & $56 \mathrm{~dB}$ & $\mathrm{x}$ & $\varnothing$ & $\mathrm{x}$ & $\mathrm{x}$ & $x$ & $\mathrm{x}$ & $\mathrm{x}$ & $\mathrm{x}$ & $\mathrm{x}$ \\
\hline 3. & $71 \mathrm{~dB}$ & $\mathrm{x}$ & $\mathrm{x}$ & $\mathrm{x}$ & $\mathrm{x}$ & $\mathrm{x}$ & $\mathrm{x}$ & $\mathrm{x}$ & $x$ & $\mathrm{x}$ \\
\hline
\end{tabular}

Berdasarkan Tabel 12 Uji Performa Speech Recognition pada Jarak, didapat bahwa penggunaan speech recognition yang terlalu dekat $(<=3 \mathrm{~cm})$ tidak dapat dideteksi dengan baik untuk ketiga kategori diatas dan jarak maksimal yang dapat dideteksi dengan baik pada tempat yang memiliki tingkat kebisingan $31 \mathrm{~dB}$ (lemah) adalah $250 \mathrm{~cm}$, untuk tempat yang memiliki tingkat kebisingan $56 \mathrm{~dB}$ (sedang) keywords hanya dapat dideteksi pada jarak 4-20 $\mathrm{cm}$, dan untuk tempat yang memiliki tingkat kebisingan $71 \mathrm{~dB}$ (keras) speech recognition tidak dapat mendeteksi input jawaban dari pemain.

Dari hasil pengujian yang telah dilakukan, didapat bahwa semakin rendah tingkat kebisingan (noise) pada suatu tempat, maka deteksi jawaban berupa suara dari pemain dapat dideteksi pada jarak yang lebih jauh dibandingkan dengan tempat atau ruangan yang memiliki tingkat kebisingan yang tinggi.

\subsubsection{Performa Spesifikasi Android}

Dilakukan pengujian performa speech recognition berdasarkan spesifikasi Android untuk melihat lama pendeteksian input jawaban berupa suara dari pemain. Pengujian ini menggunakan Android yang dimiliki oleh 33 peserta didik SMP Dharma Loka Pekanbaru yang terkait dengan pengujian dan 1 Android tambahan milik Penulis. 
Tabel 13. Uji Performa Speech Recognition dari Spesifikasi Android

\begin{tabular}{|c|c|c|c|c|c|c|}
\hline No & $\begin{array}{l}\text { Merk } \\
\text { Android }\end{array}$ & $\begin{array}{c}\text { Tipe } \\
\text { Android }\end{array}$ & Jenis Processor & $\begin{array}{l}\text { Total } \\
\text { RAM }\end{array}$ & $\begin{array}{c}\text { Sisa } \\
\text { RAM } \\
\text { Tersedia }\end{array}$ & $\begin{array}{c}\text { Lama Detelsi } \\
\text { Suara } \\
\text { (second dan } \\
\text { miliseconds) }\end{array}$ \\
\hline 1 & Samsung & JlAce & QuadCore, $1.2 \mathrm{GHz}$ & $1 \mathrm{~GB}$ & $407 \mathrm{MB}$ & $04: 32$ \\
\hline 2 & Oppo & $\mathrm{F} 1+$ & $\begin{array}{c}\text { Octa-core, } 4 \times 2.0 \text { GHz Contex- } \\
\text { A53 }\end{array}$ & $4 \mathrm{~GB}$ & $470 \mathrm{MB}$ & $02: 16$ \\
\hline 3 & Vivo & Y21 & Quad-core, $1.3 \mathrm{GHz}$ & $1 \mathrm{~GB}$ & $515 \mathrm{MB}$ & $03: 94$ \\
\hline 4 & Samsung & $\begin{array}{l}\text { Galaxy } \\
\text { Tab 3 }\end{array}$ & Dral-core, $1.2 \mathrm{GHz}$ & $3 \mathrm{~GB}$ & $1,6 \mathrm{~GB}$ & $02: 04$ \\
\hline 5 & Samsung & $\begin{array}{c}\text { Galasy } \\
\text { Tab 3 } \\
\end{array}$ & Dual-core, $1.2 \mathrm{GHz}$ & $2 \mathrm{~GB}$ & $461 \mathrm{MB}$ & $04: 51$ \\
\hline 6 & Xiaomi & Redmi 3 & $\begin{array}{c}\text { Octa-core, } 4 \times 1.5 \text { GHz Cortex- } \\
\text { A.53 }\end{array}$ & $2 \mathrm{~GB}$ & $849 \mathrm{MB}$ & $01: 47$ \\
\hline 7 & Asus & Zenfone 3 & Octa-core $2.0 \mathrm{GHz}$ Cortex-A53 & $2 \mathrm{~GB}$ & $751 \mathrm{MB}$ & $01: 73$ \\
\hline 8 & LG & Stylus 3 & $\begin{array}{c}\text { Octa-core } \begin{array}{c}1.5 \mathrm{GHz} \text { Contex-A53 } \\
-\mathrm{M} 400 \mathrm{DK}\end{array} \\
\end{array}$ & $1,8 \mathrm{~GB}$ & $502 \mathrm{MB}$ & $01: 86$ \\
\hline 9 & Xisomi & Redmi 3 & $\begin{array}{c}\text { Octa-core, } \\
4 \mathrm{x} 1.5 \mathrm{GHz} \text { Cortex- } \\
\mathrm{A} 53\end{array}$ & $3 \mathrm{~GB}$ & $722 \mathrm{MB}$ & $01: 51$ \\
\hline 10 & Vivo & V5s & Octa-core $1.5 \mathrm{GHz}$ Cortex-A53 & $4 \mathrm{~GB}$ & $1,01 \mathrm{~GB}$ & $01: 44$ \\
\hline 11 & Xisomi & $\mathrm{Mi} 4$ & Quad-core $2.5 \mathrm{GHz}$ Krait 400 & $3 \mathrm{~GB}$ & $1 \mathrm{~GB}$ & $02: 56$ \\
\hline 12 & Oppo & $\mathrm{NeO} 5$ & Quad-ore $1.2 \mathrm{GHz}$ Cortex-A7 & $1 \mathrm{~GB}$ & $334 \mathrm{MB}$ & $04: 03$ \\
\hline 13 & Samsung & $\begin{array}{l}\text { Galaxy } \\
\text { Tab 3 } \\
\end{array}$ & Dual-core, $1.2 \mathrm{GHz}$ & $1,5 \mathrm{~GB}$ & $90 \mathrm{MB}$ & $05: 04$ \\
\hline No & $\begin{array}{l}\text { Merk } \\
\text { Android }\end{array}$ & $\begin{array}{l}\text { Tipe } \\
\text { Android }\end{array}$ & Jenis Processor & $\begin{array}{l}\text { Total } \\
\text { RAM }\end{array}$ & $\begin{array}{l}\text { Sisa } \\
\text { RAM } \\
\text { Tersedia }\end{array}$ & $\begin{array}{c}\text { Laman Detelsi } \\
\text { Suara } \\
\text { (second dan } \\
\text { miliseconds) }\end{array}$ \\
\hline 14 & Samsung & A9 Pro & $\begin{array}{c}\text { Octa-core } 4 \times 1.8 \mathrm{GHz} \text { Contex- } \\
\mathrm{A} 72\end{array}$ & $2 \mathrm{~GB}$ & $271 \mathrm{MB}$ & 01:94 \\
\hline 15 & Samsung & $\begin{array}{l}\text { Galaxy } \\
\text { Grand } \\
\text { Quatro }\end{array}$ & 1.2 $\mathrm{GHz}$ Quad Core & $1 \mathrm{~GB}$ & $243 \mathrm{MB}$ & $04: 43$ \\
\hline 16 & Vivo & v5s & Octa-core $1.5 \mathrm{GHz}$ Cortex-A53 & $4 \mathrm{~GB}$ & $1,72 \mathrm{~GB}$ & $01: 32$ \\
\hline 17 & LG & Stylus 3 & 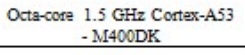 & $3 \mathrm{~GB}$ & $169 \mathrm{MB}$ & $02: 63$ \\
\hline 18 & Samsung & $\begin{array}{c}\text { Galaxy J1 } \\
\text { Mini }\end{array}$ & QuadCore, $1.5 \mathrm{GHz}$ & $4 \mathrm{~GB}$ & $1,04 \mathrm{~GB}$ & $02: 30$ \\
\hline 19 & Asus & Zenfone 5 & $\begin{array}{c}\text { Dual-core } 1.6 \mathrm{GHz} \text {, Intel Atom } \\
\mathrm{Z22560}\end{array}$ & $2 \mathrm{~GB}$ & $832 \mathrm{MB}$ & $04: 25$ \\
\hline 20 & Asus & Zenfone 3 & Octa-core $2.0 \mathrm{GHz}$ Cortex-A53 & $2 \mathrm{~GB}$ & $603 \mathrm{MB}$ & $01: 78$ \\
\hline 21 & Xisomi & $\mathrm{Mi} 4$ & Quad-core $2.5 \mathrm{GHz}$ Krait 400 & $2 \mathrm{~GB}$ & $463 \mathrm{MB}$ & $04: 07$ \\
\hline 22 & Lenovo & A2010 & Quad-core $1 \mathrm{GHz}$ & $1 \mathrm{~GB}$ & $333 \mathrm{MB}$ & $04: 18$ \\
\hline 23 & Xiaomi & $\begin{array}{c}\text { Redmi } \\
\text { Note } 3 \\
\text { P10 } \\
\end{array}$ & $\begin{array}{l}\text { Quad-core } 1.2 \mathrm{GHz} \text { Contex- } \\
\text { A53 }\end{array}$ & $3 \mathrm{~GB}$ & $530 \mathrm{MB}$ & $03: 21$ \\
\hline 24 & Xisomi & $\begin{array}{l}\text { Redmi } \\
\text { Note } 3 \\
\end{array}$ & Octa-core & $3 \mathrm{~GB}$ & $815 \mathrm{MB}$ & $01: 58$ \\
\hline 25 & Xiaomi & $\begin{array}{r}\text { Redmi } \\
\text { Note } 4 \mathrm{x} \\
\end{array}$ & Octa-core $2.0 \mathrm{GHz}$ Cortex-A53 & $4 \mathrm{~GB}$ & $190 \mathrm{MB}$ & $02: 44$ \\
\hline 26 & Oppo & $\mathrm{A} 37$ & $\begin{array}{l}\text { Quad-core } 1.2 \mathrm{GHz} \text { Contex- } \\
\text { A53 }\end{array}$ & $2 \mathrm{~GB}$ & $804 \mathrm{MB}$ & $03: 88$ \\
\hline 27 & Asus & Zenfone 2 & $\begin{array}{c}\text { Super Quad- Core Intel Atom } \\
\text { (Intel Atom Z3580, Quad-Core } \\
2.3 \mathrm{GHz} \text { ) }\end{array}$ & $1,8 \mathrm{~GB}$ & $354 \mathrm{MB}$ & $02: 72$ \\
\hline 28 & Oppo & F3 & $\begin{array}{c}\text { Octa-core Qualcomm } \\
\text { MSMB9976 }\end{array}$ & $4 \mathrm{~GB}$ & $768 \mathrm{MB}$ & $01: 65$ \\
\hline 29 & Samsung & $\begin{array}{l}\text { Galaxy } \\
\text { Tab 3 }\end{array}$ & Dual-core, $1.2 \mathrm{GHz}$ & $2 \mathrm{~GB}$ & $350 \mathrm{MB}$ & $04: 72$ \\
\hline 30 & Samsung & $\begin{array}{l}\text { Galaxy } \\
\mathrm{Tab}_{3} \\
\end{array}$ & Dual-core, $1.2 \mathrm{GHz}$ & $2 \mathrm{~GB}$ & $132 \mathrm{MB}$ & $05: 27$ \\
\hline 31 & Asus & Zenfone 3 & Octa-core $2.0 \mathrm{GHz}$ Cortex-A53 & $2 \mathrm{~GB}$ & $136 \mathrm{MB}$ & $03: 17$ \\
\hline 32 & Oppo & Neo R381 & Dual-core $1.3 \mathrm{GHz}$ & $4 \mathrm{~GB}$ & $\begin{array}{c}59,20 \\
\text { MB } \\
\end{array}$ & $05: 45$ \\
\hline 33 & Xiaomi & $\begin{array}{l}\text { Redmi } \\
\text { Note } 3 \\
\end{array}$ & Octa-core & $3 \mathrm{~GB}$ & $1,3 \mathrm{~GB}$ & 01:39 \\
\hline 34 & Vivo & $\mathrm{V} 7$ & Octa-core, $1.8 \mathrm{GHz}$ & $4 \mathrm{~GB}$ & $1,25 \mathrm{~GB}$ & $01: 28$ \\
\hline
\end{tabular}

Dari hasil visualisasi dalam bentuk tabel pengolahan pada Tabel 13 Uji Performa Speech Recognition dari Spesifikasi Android

70 Raymond diatas, deteksi jawaban (suara) paling cepat pada processor Octacore, $1.8 \mathrm{GHz}$, dengan total RAM keseluruhan yaitu $4 \mathrm{~GB}$, dan 
RAM yang masih tersisa sebesar 1,25 GB dengan lama deteksi suara selama 01:28 detik dan yang membutuhkan waktu paling lama dalam melakukan deteksi adalah processor Dual-core 1.3 $\mathrm{GHz}$ dengan total RAM sebesar $4 \mathrm{~GB}$ dan alokasi RAM yang masih tersedia sebesar 59,20 MB 05:45 detik.

Berdasarkan hasil diatas, didapat bahwa semakin tinggi processor yang digunakan pada sebuah Android dan total RAM pada Android tersebut besar, maka kinerja untuk penangkapan suaranya lebih cepat. Lama durasi penangkapan input jawaban dari pemain juga didukung dengan total RAM yang masih tersedia pada Android yang digunakan, semakin banyak total RAM yang tersedia atau tersisa, maka kinerja penangkapan suara pada speech recognition semakin cepat.

\section{KESIMPULAN DAN SARAN}

\subsection{Kesimpulan}

Adapun kesimpulan yang diperoleh dari hasil analisa yang didapatkan terhadap data pengujian adalah sebagai berikut:

1. Game Memory Training yang dibangun dapat membantu memvisualisasikan dan melihat nilai perkembangan memori jangka pendek yang didapatkan oleh pemain, meningkatkan kemampuan Short Term Memory (STM) peserta didik SMP Dharma Loka Pekanbaru sebesar 93,9\% untuk Memory Test dan 69,7\% untuk Concentration Test dari total keseluruhan siswa yang terkait dengan pengujian.

2. Berdasarkan pengujian dengan menggunakan metode wawancara, Game Memory Training yang dibangun, telah mengacu pada form Wechsler dan IST yang merupakan alat test intelegensi yang digunakan pada bidang psikologi dan berdasarkan pengujian blackbox menggunakan testcase, fungsionalitas yang terdapat pada game $100 \%$ telah valid.

3. Pronounciation dalam Bahasa Inggris yang dimiliki oleh pemain (siswa SMP) mempengaruhi nilai dan lama durasi yang didapatkan pada saat pengerjaan soal pada Game Memory Training, adapun keywords yang sulit untuk dideteksi yaitu "two", "four", "three", "eight", "vase", "scissors", "noun", dan "fruit". Hal ini terkait dengan adanya perbedaan penulisan dengan cara pengucapan dalam bahasa Inggris ketika dilafalkan dan tidak semua peserta didik memiliki pronounciation yang baik.

4. Saat memainkan game pada suasana yang ramai, penggunaan microphone dalam menangkap suara pada Game Memory Training lebih baik dibandingkan tanpa menggunakan microphone, karena hal ini terkait dengan tingkat kebisingan (noise) pada saat mendeteksi input jawaban dari pemain.

5. Berdasarkan uji performa spesifikasi Android, didapatkan bahwa semakin tinggi processor yang digunakan dan alokasi RAM yang masih tersedia besar pada Android, maka semakin cepat untuk mendeteksi input jawaban berupa suara dari para pemain.

6. Berdasarkan uji performa pada jarak, semakin rendah tingkat kebisingan (noise) pada suatu tempat, maka deteksi jawaban berupa suara dari pemain dapat dideteksi pada jarak yang lebih jauh dibandingkan dengan tempat atau ruangan yang memiliki tingkat kebisingan (noise) yang tinggi.

\subsection{Saran}

1. Dibutuhkan pengembangan lebih lanjut untuk memainkan Game Memory Training ini pada tempat yang memiliki tingkat kebisingan (noise) yang tinggi.

2. Dibutuhkan pengembangan lebih lanjut pada penggunaan $X M L$ sebagai media penyimpanan data pada Game Memory Training yang telah dibangun.

\section{DAFTAR PUSTAKA}

[1] Atkinson, R., \& Shiffrin, R. (1998). Jenis-Jenis Memori Manusia. Dipetik 11 Juni 2017, dari Kompasiana Website: http://www.kompasiana.com/ali 91/apa-itumemori-manusia 54f94aaba33311ba078b49f2

[2] Form Wechsler. (2016). Sekilas Mengenai WAIS (Wechsler Adult Intelligence Scale). Dipetik 12 Juni 2017, dari Psikologi Mania Website: http://www.psikoma.com/sekilas-mengenai-waiswechsler-adult-intelligence-scale/

[3] Jones, A. (2010). Music and the cognitive process student perceptions. Polyglossia. 19. 143-150.

[4] Kartono. (1990). Batasan Usia Remaja. Dipetik 11 Juni 2017, dari Belajar Psikologi Website http://belajarpsikologi.com/batasan-usia-remaja/

[5] Kuswardayan, I., Ericksoon, H. A., \& Suciati, E. N. (2016). Rancang bangun game berhitung spaceship dengan pengendali suara menggunakan speech recognition plugin pada unity. Surabaya: Institut Teknologi Sepuluh Nopember (ITS).

[6] Kartono. (1990). Batasan Usia Remaja. Dipetik 11 Juni 2017, dari Belajar Psikologi Website: http://belajarpsikologi.com/batasan-usia-remaja/

[7] Miller, G.A. (1956). The Magical Number Seven, Plus or Minus Two Some Limits on Our Capacity for Processing Information. 63 (2), pp. 81-97.

[8] Permadi, T. (2008). Pemanfaatan microsoft speech application programming interface pada pembuatan aplikasi perintah suara. Jakarta: Universitas Pembangunan Nasional Veteran Jakarta.

[9] Pope, Kelsey. (2017). The effects of jazz and classical music on recall. Journal of Health Education Reseach \& Development. 5(2). 1-3.

[10] Rumini, S., \& Sundari, S. (2004). Perkembangan Psikologi Remaja. Dipetik 11 Juni 2017, dari Belajar Psikologi Website: http://belajarpsikologi.com/perkembangan-psikologisremaja/

[11] Safaat H., N. (2011). Pemrograman aplikasi mobile smartphone dan tablet PC berbasis Android. Bandung: Penerbit Informatika.

[12] Sasmita, N. O. (2010). Pengujian validitas konstruk dar Intelligenz Structure Test (IST) yang telah direvisi Badan Pengkajian dan Penerapan Teknologi (BPPT). Jakarta: Universitas Islam Negeri Syarif Hidayatullah

[13] Trisnadoli, A. (2015). Analisis kebutuhan kualitas perangkat lunak pada software game berbasis mobile. Pekanbaru: Politeknik Caltex Riau. Dipetik 11 Juni 2017 Website: https://jurnal.pcr.ac.id/index.php/jkt/article/view/20 


\section{BIODATA PENULIS}

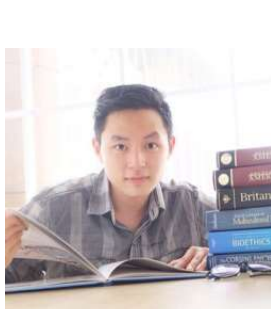

Raymond

Lahir di Pekanbaru, 25 Desember 1996. Saat ini, berkuliah di Politeknik Caltex Riau pada program studi Teknik Informatika, Jurusan Komputer.

\section{Rahmat Suhatman, S.T., M.T.}

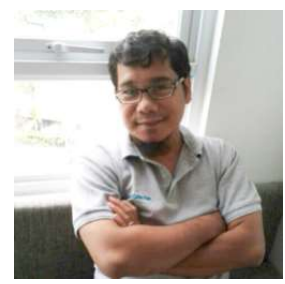

Saat ini berkarir sebagai dosen di Kampus Politeknik Caltex Riau Adapun bidang kompetensi yang dinaungi yaitu Computer Networking, Operating System, dan

Meilany Dewi, S.T., M.T.

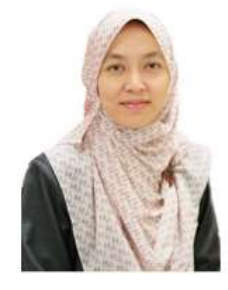

Lahir di Pekanbaru, 21 Mei 1980. Saat ini berkarir sebagai dosen di kampus Politeknik Caltex Riau pada Program studi Teknik Informatika, Kompetensi yang diampuh yaitu Digital Video Processing, Computer Animation. dan mengajar mata kuliah Animation Computer. 